Engineering in Chalk

Proceedings of the Chalk 2018 Conference

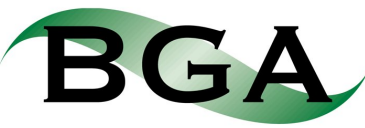

- THE BRITISH .

GEOTECHNICAL

ASSOCIATION
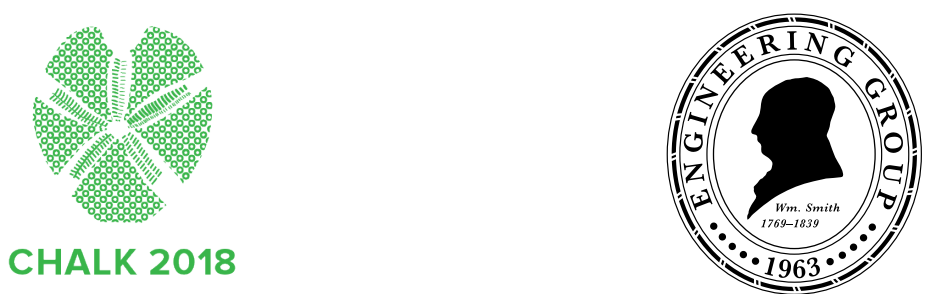
Downloaded by [] on [26/04/23]. Copyright $\odot$ ICE Publishing, all rights reserved. 


\section{Engineering in Chalk}

Proceedings of the Chalk 2018 Conference Imperial College, London on 17 and 18 September 2018

Hosted by the British Geotechnical Association (BGA) with support from the Engineering Group of the Geological Society (EGGS)

Edited by

J.A. Lawrence, M. Preene, U.L. Lawrence and R. Buckley 
Published by ICE Publishing, One Great George Street, Westminster, London SW1P 3AA.

Full details of ICE Publishing representatives and distributors can be found at:

www.icebookshop.com/bookshop_contact.asp

www.icebookshop.com

A catalogue record for this book is available from the British Library

ISBN 978-0-7277-6407-2

(C) The Authors 2018

ICE Publishing is a division of Thomas Telford Ltd, a wholly-owned subsidiary of the Institution of Civil Engineers (ICE).

All rights, including translation, reserved. Except as permitted by the Copyright, Designs and Patents Act 1988, no part of this publication may be reproduced, stored in a retrieval system or transmitted in any form or by any means, electronic, mechanical, photocopying or otherwise, without the prior written permission of the Publisher, ICE Publishing, One Great George Street, Westminster, London SW1P 3AA.

This book is published on the understanding that the authors are solely responsible for the statements made and opinions expressed in it and that its publication does not necessarily imply that such statements and/or opinions are or reflect the views or opinions of the publishers. While every effort has been made to ensure that the statements made and the opinions expressed in this publication provide a safe and accurate guide, no liability or responsibility can be accepted in this respect by the authors or publishers.

While every reasonable effort has been undertaken by the author and the publisher to acknowledge copyright on material reproduced, if there has been an oversight please contact the publisher and we will endeavour to correct this upon a reprint.

Cover photo: Excavation of the Seaford Chalk Formation in Shaft G at Abbey Mills Pumping Station during construction of the Thames Water Lee Tunnel, London. Photograph courtesy of Tim Newman. Reproduced with permission of Thames Water.

Commissioning Editor: Michael Fenton

Development Editor: Inês Pinheiro

Production Editor: Madhubanti Bhattacharyya

Marketing Specialist: April Asta Brodie

Typeset by The Manila Typesetting Company

Printed and bound in Great Britain by TJ International Padstow 


\section{Contents}

Conference Organising Committee

Preface

Avant-propos

Introduction to Engineering in Chalk: the Chalk 2018 conference

M. PREENE

\section{Keynote Papers}

Developing ground models for chalk engineering: links across the disciplines

R.N. MORTIMORE

Behaviour of piles driven in chalk

R.J. JARDINE, R.M. BUCKLEY, S. KONTOE, P. BARBOSA AND F.C. SCHROEDER

Review of collapse events on chalk since 2000 and the opportunities for improved engineering practice

\section{Andrew Lord Memorial papers}

Andrew Lord Memorial Paper: Design and specification of chalk earthworks for High Speed One

A.G. PHEAR, C.A. BARKER AND N.J. O'RIORDAN

Design, construction and performance of chalk trackbed for High Speed One

C.A. BARKER, A.G. PHEAR AND N.J. O’RIORDAN

Construction and performance of chalk earthworks for High Speed One

A.G. PHEAR, C.A. BARKER AND N.J. O'RIORDAN

\section{Case histories of construction and engineering}

Integrating Victorian engineering into an observational approach to slope design

M.J. BALDWIN

Design and construction of the chalk earthworks for the A41 Aston Clinton Bypass

L.H. BURT AND A.G. PHEAR

Installation and axial capacity of the Sheringham Shoal offshore wind farm monopiles - a case history

Historical chalk quarries: redevelopment and geo-conservation challenges

C.N. EDMONDS AND G.P. WIGGIN

Recent experiences of full scale static pile load testing in chalk

M. ENGLAND AND P. CHEESMAN

Case studies of dewatering projects in chalk

M. FONTY, S. GHEGEDIBAN AND B. GIACOMETTI

Investigation and characterization of highly weathered valley bottom chalk for viaduct pile foundations

T. HOCOMBE, S. JARVIS, T. BROOKS AND R. CONFORTI

A case study of construction dewatering in Northern Province Chalk 
Groundwater challenges in the limestone during construction of metro and roadway tunnels to a new waterfront city district in Copenhagen

L.M. MARKUSSEN, S.B. HANSEN AND L.K. OLSEN

Best practice for the treatment of high and steep chalk slopes over infrastructure

A.G. MORRIS AND A.J. O’DONOVAN

Remediation of a 125 year old Metropolitan London Underground chalk cutting at Chalfont

S.K. MORTIMORE, P.A. NOWAK AND N. SAFFARI

\section{Earthworks}

Back analysis of static load tests of CFA piles in chalk

J.W. SPYVEE, A.T. CARVALHO AND D.A. HARD

Spire London - testing and behaviour of a deep rock socket in chalk using the Osterberg method

D. HARD, T. HARTLIB AND M. ENGLAND

Site investigation for HS2 across the Colne Valley and Chiltern Hills

K. REEVES, C.D. WARREN, G. DOWLEN AND Y. LIU

A new methodology for geotechnical risk management and land planning in Wallonia, Belgium: application to underground workings in the Hesbaye region

A. KHEFFI, D. PACYNA, M. SALMON, L. FUNCKEN, C. SCHROEDER AND J.P. TSHIBANGU

Foundations and piling

Tight chalk: How does microtexture control petrophysical and geomechanical properties? The role of clay flakes and calcite cements 229 O. FAŸ-GOMORD, F. DESCAMPS, J. SOETE, S. VANDYCKE, J.P. TSHIBANGU AND R. SWENNEN

Ipswich barrier: design of piled foundations for the main barrier structure

P.A. NOWAK AND R. THIJSSEN

Monitoring and performance of deep basement excavation at Royal Sussex County Hospital, Brighton

S. SRISAKTHIVEL, T. HAYWARD AND K.S. MILLER

Analysis of preliminary pile load tests in chalk at Basingstoke

K.S. MILLER

Foundations in low density chalk - a practitioner's perspective

P.J.H. BOYD

\section{Future engineering issues}

The development of a chalk terrain ground model using an integrated approach with high resolution LiDAR and SAR with geophysical data sets. A case study from South Hampshire

S. PENN AND D.P. GILES

PSInSAR remote sensing observations of deformation behaviour at Salisbury Plain, UK

S.A. AGAR, J.A. LAWRENCE, R.C. GHAIL, P.J. MASON AND S. THOMPSON

A constitutive model for the hydro-chemo-mechanical behaviour of chalk

M.O. CIANTIA

Management of chalk cuttings on the London Underground (LU) network

N. SAFFARI AND N.A. ESSLEMONT

Use of chalk on the A160 Port of Immingham Improvement scheme

T. MAGALHAES, S. AKHTAR AND P. GILBERT

Engineering challenges building on Grade D Chalk in East Anglia

M.G. WILLIAMSON AND S.A. SOLERA

\section{Geological hazards}

Continuous surface wave testing as a new addition to the holistic approach of treating abandoned chalk mines and collapse features in chalk

E. WOOD, C. MILNE AND A. O’DONOVAN

The role of chalk in the development of buried ("drift-filled") hollows 
Rail tunnels through chalk cliffs: the importance of remote sensing and geotechnical mapping in developing an understanding of cliff regression

L. MILES, L. KINGDOM AND S. LIGHTBODY

Influence of brittleness of soft calcarenites in cliff stability problems: insights from FEM-DEM modelling

P. LOLLINO, M.D. PESOLA, N.L. FAZIO, M. PERROTTI AND G.F. ANDRIANI

Natural experiments in rock mechanics using high precision monitoring of chalk sea cliffs

J. BARLOW, R. MOORE AND J. GILHAM

Multi-sensor laser scan survey techniques for coastal landslide and chalk cliff monitoring and analysis at Folkestone Warren

I. ANDERSON, C.D. WARREN AND D. BUTCHER

Periglacial weathering and disturbance below valley bottoms

A.V.J. COLLINGS

The stabilisation of abandoned chalk mines in Chantry Lane, Hatfield

D. LEWIS AND A. O’DONOVAN

Erosion of the chalk coastal cliffs at Birling Gap, Sussex, UK. Correlation between rate of coastal retreat, geotechnical rocks properties and precipitation

S.G. ASONI, A. STAVROU AND J.A. LAWRENCE

Developing a GIS based methodology for coastal chalk cliff retreat using multiple datasets

S.G. ASONI, A. STAVROU AND J.A. LAWRENCE

The use of geosynthetics in ground subsidence risk mitigation

G. HORGAN, I. SCOTLAND AND H. HANGEN

Offshore engineering

Relationships between reservoir properties and production-related changes in effective vertical stress (the Kraka Field, Danish North Sea)

F. AMOUR, M. WELCH, S. SEYUM AND E. GALDAL

Full Scale Instrumented Pile Response in Moderately Cemented Calcareous Soil

B.S. RIYAT AND B.M. LEHANE

Use of biostratigraphy techniques to inform subsea cable burial projects in chalk: a case study

J.R. PYRAH, L. GALLAGHER, S. METCALFE AND S. SHEPPERSON

Offshore static and dynamic pile load tests results in low density chalk Grade A1/A2 to optimize the foundation design of jacket piles M. GEDUHN, P. BARBOSA AND J. DÜHRKOP

\section{Site investigation/characterisation}

High-resolution stratigraphy and physical property modelling of the Chalk

M.A. WOODS, A.J. NEWELL, A.R. FARRANT, R.B. HASLAM AND S.M. CLARKE

The investigation and characterisation of the Chalk and overlying Thames deposits at Tilbury, Essex, UK

D.S. FORT, S. MORTIMORE, C.E. BRANNIGAN AND J. GEEAR

Chalk permeability

T.O.L. ROBERTS AND D.J. HARTWELL

Use of rota-sonic drilling to investigate deep London Basin geology: a case study for an urban East London environment, including comparison to a conventionally drilled borehole

E. RILEY, M. BELLHOUSE, R. MORTIMORE AND A. CONDRON

A collaborative approach to high quality ground investigation required for the design of five deep Thames Tideway Tunnel shafts M. VANCE, M. BELLHOUSE, P. HEPTON AND R. TALBY

The Chalk revolution - the role of geological mapping for engineering and hazard assessment 
Flamborough and Burnham Chalk - measured properties and characteristics of some northern chalks

\section{Testing: in situ and laboratory}

The effect of the remoulded void ratio on unit shaft friction in small-displacement piles in chalk

F.J. ALVAREZ-BORGES, C.R.I. CLAYTON, D.J. RICHARDS AND B.N. MADHUSUDHAN

Anisotropic permeability of chalk

G. MIDER AND J.A. LAWRENCE

The role of suspension and dissolution on strength and deformation of soft carbonate rocks

M.O. CIANTIA, R. CASTELLANZA, G.B. CROSTA, G. FRIGERIO, C. DI PRISCO AND T. HUECKEL

J.B. MURTON

Time and stress dependent strength and stiffness of reconstituted chalk

G.A. BIALOWAS AND A. DIAMBRA

Determination of chalk structure using cone penetration tests

M. BROWN, L. TAYLOR AND T. SADEK

Impact of tectonic faults on the morphology and mechanical properties of grey flints

M.M. ALIYU, W. MURPHY, J.A. LAWRENCE AND R. COLLIER

Characterising chalk-concrete interfaces for offshore renewable energy foundations

A. ZIOGOS, M.J. BROWN, A. IVANOVIC AND N. MORGAN

Developing pore size distribution models in the heterogeneous carbonates using especially nuclear magnetic resonance

D. HUSSEIN, J. LAWRENCE, F. RASHID, P. GLOVER AND P. LORINCZI

R.D. MUHAMMED, J. CANOU, J.-C. DUPLA, E. PALIX AND M. DUC

Failure characterization in geomechanical testing using nuclear magnetic resonance spectroscopy

L.T.P. MEIRELES, C. RAVNÅS, M.J. WELCH AND I.L. FABRICIUS

Macro and micro fabrics in chalk identified using the Bushinsky Oil Technique: an updated method and new applications for an old experimental technique

J.A. LAWRENCE, R.N. MORTIMORE AND A. THROWER

Experimental study of the water weakening of carbonate rocks

M.O. CIANTIA

Application of X-ray computed tomography to investigate pile penetration mechanisms in chalk

F.J. ALVAREZ-BORGES, D.J. RICHARDS, C.R.I. CLAYTON AND S.I. AHMED

\section{Tunnelling}

Historical chalk mines below Pinner Wood School

M. HUDSON AND S.J. CHANDLER

The Channel Tunnel Study Group - an Anglo French adventure in the Chalk

M. PREENE AND A. DAVEY

Geology and geotechnics of the HS1 North Downs tunnel

Properties of Lower, Middle \& Upper Chalk from the HS1 North Downs tunnel

C.D. WARREN AND A. SIMANTIRAKIS

Historical mining in chalk - utilising temporal and spatial research for identifying and assessing occurrence, scale, duration, physical form and extent, and resultant geo-hazard: example of Reading, southern England J.D. FORD

Comparison of earth pressure balance and slurry tunnel boring machines for tunnelling in chalk

C. WARREN, T. NEWMAN AND N.W. HADLOW 
Water and the environment

Pumping tests for construction dewatering in chalk

M. PREENE, T.O.L. ROBERTS AND D.J. HARTWELL

Influence of moisture content on several properties of Upper Cretaceous chalk

Developments in the conceptual understanding of groundwater flow in the Chalk aquifer in London

M.J. STREETLY, P.J. DAILY, E.R. FARREN, N. HOAD AND M.A. JONES

Developments in modelling groundwater flow in the Chalk in London

M.J. STREETLY, P.J. DAILY, E.R. FARREN, N. HOAD AND M.A. JONES

Foundation risk assessment for the Chalk Group aquifer - compliance with current UK guidance

K.M. ALLSO AND S.L. WEST

Chalk fractures geometry: a comprehensive description of fracture surfaces

M.-L. WATTIER, F. DESCAMPS, S. VANDYCKE AND J.-P. TSHIBANGU

Groundwater resource protection from construction groundwater control in the Lincolnshire chalk T.L. GOODFELLOW AND S.D. THOMAS

Study of the heterogeneity of hydraulic properties in a chalk aquifer unit, using sequential pumping and tracing experiments with packer systems

P. GODERNIAUX, A. BEYEK, A. TCHOTCHOM, A. POULAIN, M.-L. WATTIER AND S. VANDYCKE

Investigation of controlling parameters on geomechanical properties of the Southern Danish Central Graben chalk

L.T.P. MEIRELES, E.M. STOREBØ, M.J. WELCH AND I.L. FABRICIUS

Long-term stress-strain response of chalk: a micro-mechanical interpretation

K.I. KATSAROS AND K.J.L STONE

Investigating the effect of ageing on the behaviour of chalk putty

L.J. DOUGHTY, R.M. BUCKLEY AND R.J. JARDINE

The use of video cone during cone penetration testing to identify and delineate chalk dissolution features

A. CADMAN AND I.M. MARYCHURCH

Evaluation and prediction of anticipated depths of weathering (engineering rockhead) as a function of geomorphology in areas of chalk outcrop in southern England and northern France

N.W. HADLOW, J.A. LAWRENCE AND R.N. MORTIMORE

Evaluation of chalk rock mass properties in subcrop and outcrop in London; examples from the Tideway and Lee tunnels

T.G. NEWMAN AND N.W. HADLOW

Communication of ground related hazards through the creation of a dissolution features hazard map for the Strategic Road Network of England

J. NEVILLE, C. POWER, T. SPINK AND D. PATTERSON

Author Index 


\section{Conference Organising Committee}

Martin Preene

James Lawrence

Alex Carbray

Patrick Cox

Gareth Swift

Róisín Buckley

Matteo O Ciantia

Ursula Lawrence
Chairman, BGA Chairman

Organising Secretary, Imperial College London

Treasurer, independent consultant

Publicity Chair, AECOM

Programme Chair, University of Portsmouth

Assistant Organising Secretary, Imperial College London

Assistant Organising Secretary, University of Dundee

Engineering Group of the Geological Society Representative, Capita

\section{Conference Scientific and Technical Theme Leaders}

Tim Newman

Keith Nicholls

David Hard

Neill Hadlow

Clive Edmonds

Miguel Andrade

Keith Reeves

Fanny Descamps

Rob Talby

Ursula Lawrence
Case histories of construction and engineering, Thames Tideway

Earthworks, Network Rail

Foundations and piling, pile design, installation, Bachy Soletanche Future engineering issues, $\mathrm{CH} 2 \mathrm{M}$ Hill

Geological hazards, Peter Brett Associates

Offshore engineering, Ørsted Energy

Site investigation/characterization, HS2

Testing - in situ and laboratory, University of Mons, Belgium

Tunnelling, Mott MacDonald

Water \& the Environment, Capita 


\section{Sponsors and Exhibitors}

The conference organisers would like to thank the sponsors and exhibitors for their important contributions and support of Chalk, 2018.

Gold Sponsor: Tideway

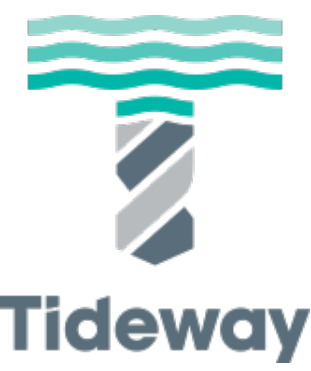

Silver Sponsors: Bam Ritchies, Peter Brett Associates
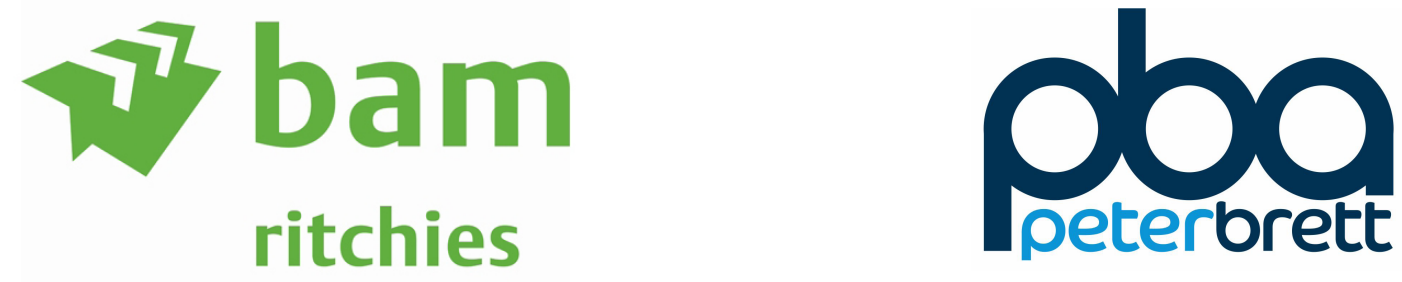

Bronze Sponsors: Fugro, SOCOTEC, WJ Groundwater
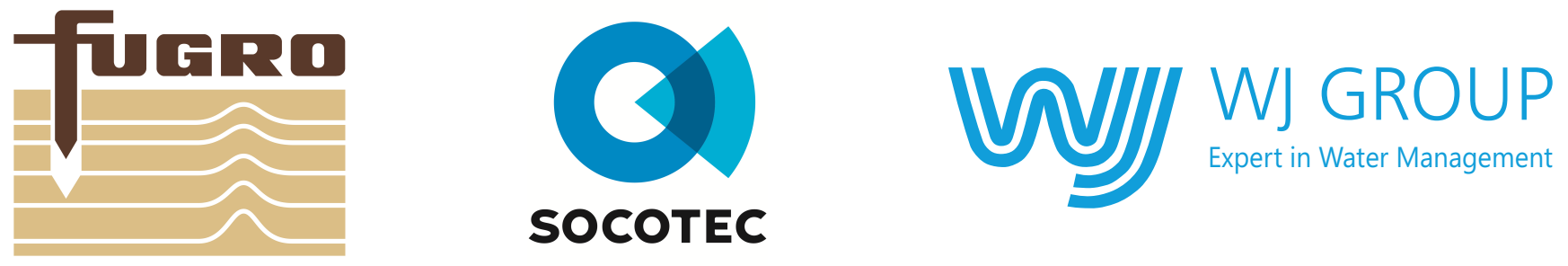
SOCOTEC 


\section{Preface}

The Chalk 2018 Engineering in Chalk conference is held at Imperial College London (UK) on 17 and 18 September 2018. The Conference has been very ably organized by the British Geotechnical Association (BGA) with the support of the Engineering Group of the Geological Society of London (EGGS). This is the first of a planned series of biennial international conferences organized by the BGA in the field of Geotechnics, providing a forum for researchers and practitioners to present new developments, to discuss relevant issues and to prepare the ground for future advances.

The theme of the Conference is Engineering in Chalk (Chalk 2018). The last major conference on chalk was held almost 30 years ago in Brighton in 1989. Since that time, considerable work has been undertaken internationally through research and practice on many major projects in the Chalk, advancing our understanding of its origin, nature and engineering behaviour. It is therefore a timely topic that provides a wide scope for participation from all specialities within this broad field. The contributions have been structured in scientific and technical themes:

- Case histories of construction and engineering,

- Earthworks,

- Foundations and piling, pile design, installation,

- Future engineering issues,

- Geological hazards,

- Offshore engineering,

- Site investigation/characterization,

- Testing - in situ and laboratory,

- Tunnelling,

- Water and the environment.

The Conference Organising Committee did not limit the number of papers that could be submitted, this has led to a wide range of participation and to a comprehensive Conference programme. The papers have been subject to internal and external review, this has led to more than 90 papers being accepted for publication. They are all presented at the Conference either as oral or poster presentations and are collected in this single volume of the Proceedings. The Proceedings contain an Introductory Paper from the Chairman of the BGA as well as three Keynote Lectures by leaders in the fields of geology and civil engineering who happen to be experts in the Chalk. The papers in this Conference demonstrate the technical challenges faced, but also provide proof of the key role scientists and engineers play in developing understanding and finding solutions when engineering in chalk.

James Lawrence

Organising Secretary

Chalk 2018 Engineering in Chalk 


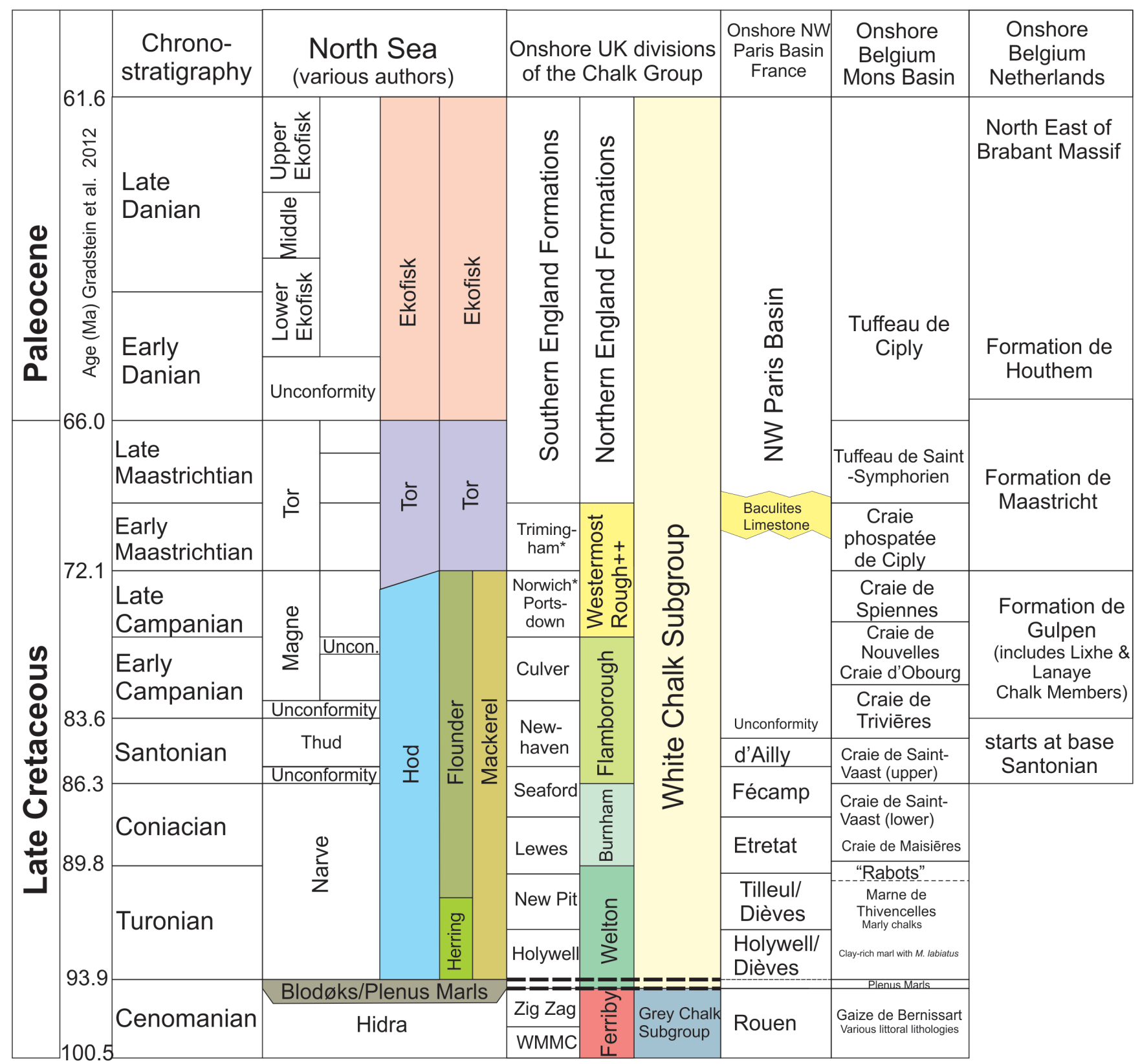

WMMC $=$ West Melbury Marly Chalk Formation Trimingham* and Norwich* informal divisions for East Anglia only ++ Offshore Yorkshire (replaces Rowe Chalk Formation)

\section{Chalk stratigraphy of Europe (Courtesy of Professor R.N. Mortimore)}




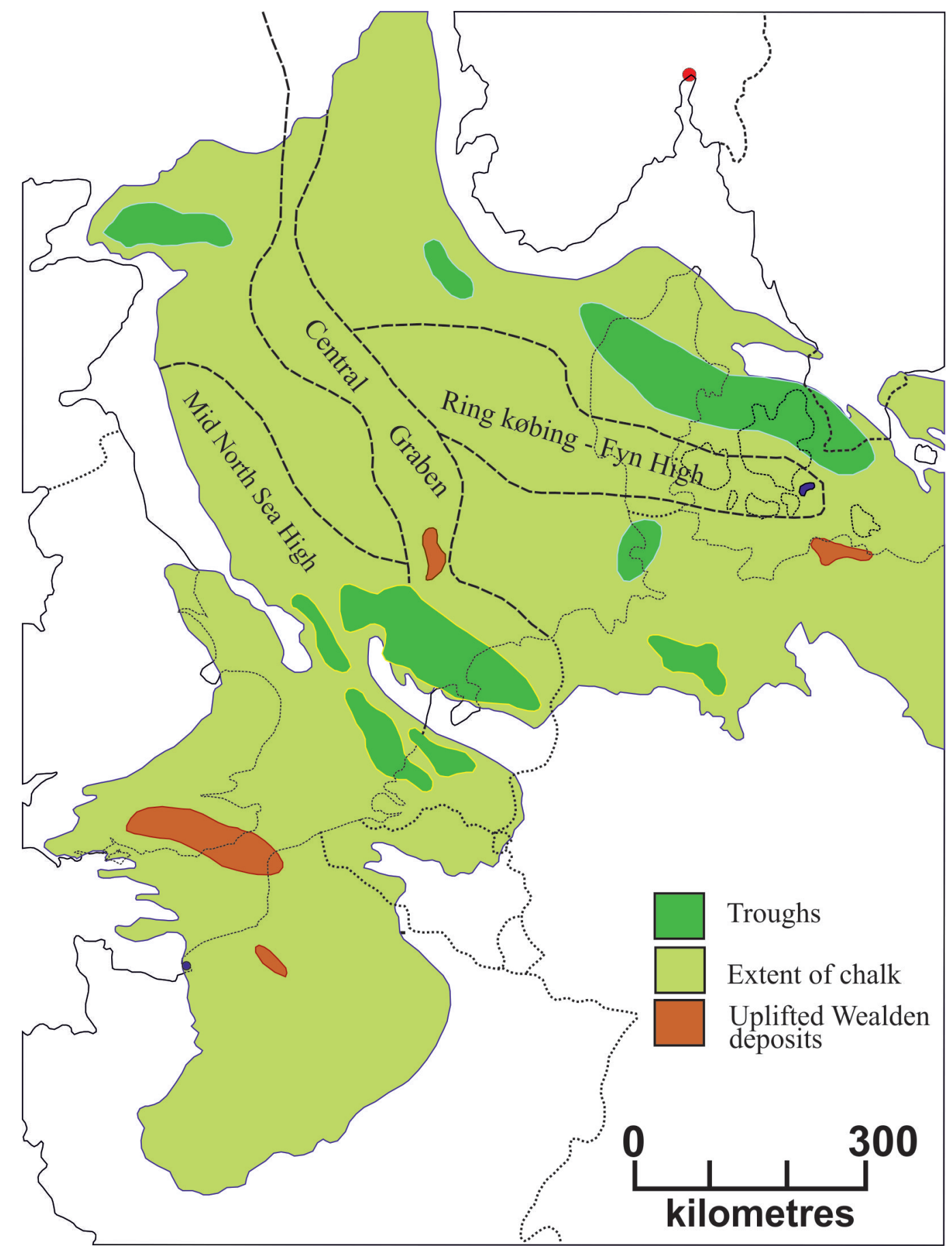

Distribution of the chalk throughout Europe (Courtesy of Professor R.N. Mortimore) 